\title{
Supracostal PCNL-Standard Nephrostomy with Day Long Pain Versus Painless Tubeless
}

\author{
Gün Boyu Ağrılı Standart Nefrostomiye Karşı Ağrısız Tüpsüz-Suprakostal PNL
}

\author{
(D) Adnan Siddiq ${ }^{1}$, (D) Salman El Khalid1, (D) Syed Mamun Mahmud², (D) Sherjeel Saulat ${ }^{3}$, (D) Shariq Anis Khan¹, \\ (D) Muhammad Hammad Mithani1 \\ 1The Kidney Centre Postgraduate Training Institute, Department of Urology, Karachi, Pakistan \\ 2 Lifecare Hospital, Clinic of Urology, Abu Dhabi, United Arab Emirates \\ 3Tabba Kidney Institute, Department of Urology, Karachi, Pakistan
}

\section{What's known on the subject? and What does the study add?}

Supracostal access during percutaneous nephrolithotomy has become a fear factor among the urological fraternity. leaving a drainage tube postoperatively has become a beacon of safety. But the evidence proving this notion is feeble. This study adds to the evidence which proves that drainage is not necessary in supracostal access during a very common urological procedure of percutaneous nephrolithotomy. Hopefully after getting replicated by other researchers, this study will shape future guidelines pertaining to treatment modalities in stone disease management.

\section{Abstract}

Objective: To determine the scope of tubeless (TL) supracostal percutaneous nephrolithotomy (PCNL) in terms of safety through a randomized controlled trial.

Materials and Methods: Adult patients (>14 years) undergoing supracostal PCNL were randomized into two groups (25 patients each), by randomizing odd number for supracostal PCNL with tube (WT) as group A and for TL supracostal PCNL as group B. Both groups received injectable analgesia on operative day and oral analgesia from the first post-operative day. Pain severity was objectively assessed by a visual analogue scale (VAS). Chest X-ray and kidney ultrasonography were done to detect any pleural effusion and perinephric collection. These complications along with thoracostomy and endotracheal intubation were compared between the groups.

Results: The mean (VAS) score in group A and B was $7.88 \pm 0.83$ and $4.12 \pm 0.83$, respectively ( $p=0.01)$. Four of 25 (16\%) patients in group $A$ and 1 of $25(4 \%)$ patients in group B developed pleural effusion. Two patients (8\%) in group A and 1 patient (4\%) in group B required tube thoracostomy $(p=0.56)$. One patient $(4 \%)$ in group $A$ and 2 patients $(8 \%)$ in group B developed perinephric collection $(p=0.56)$. A single patient in each group ( $2 \%)$ developed respiratory distress needing elective intubation and ventilation $(p=1.00)$.

The mean hospital stay in group B ( $4.12 \pm 0.52$ days) was shorter than in group $A(4.68 \pm 0.85$ days $)(p=0.01)$.

Conclusion: Tubeless supracostal PCNL is less painful than supracostal PCNL WT, without difference in complication rates. Supracostal PCNL (TL) has a shorter hospital stay.

Keywords: Percutaneous nephrolithotomy, Supracostal, Pleural effusion, Thoracostomy

$0 \ddot{z}$

Amaç: Tüpsüz suprakostal perkütan nefrolitotominin (PNL), randomize kontrollü çalışma ile güvenlik açısından kapsamını belirlemek.

Gereç ve Yöntem: Suprakostal PNL uygulanan erişkin hastalar (>14 yıl), tüplü suprakostal PNL için A grubu olarak ve tüpsüz suprakostal PNL için B grubu olarak iki gruba tek sayı randomize edildi (her biri 25 hasta). İki grup ameliyat günü enjektabl analjezi ve operasyon sonrası ilk günden itibaren oral analjezi aldı. Ağrı şiddeti görsel analog ölçeği (GAÖ) ile objektif olarak değerlendirildi. Plevral efüzyon ve perinefrik koleksiyonu saptamak için göğüs X-ray ve böbrek ultrasonu yapıldı. Torakostomi ve endotrakeal entübasyon ile birlikte bu komplikasyonlar gruplar arasında karşılaştırıldı.

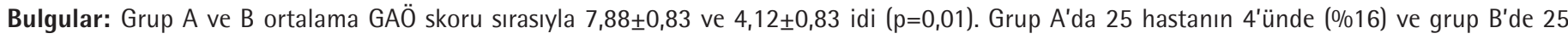

Correspondence: Adnan Siddiq MD, The Kidney Centre Postgraduate Training Institute, Department of Urology, Karachi, Pakistan

Phone: +92-2136683032Ｅ-mail: dradnansiddiq@hotmail.com ORCID-ID: orcid.org/0000-0002-8587-9397

Received: 18.12.2017 Accepted: 19.03.2018

Cite this article as: Siddiq A, El Khalid S, Mahmud SM, Saulat S, Khan SA, Mithani MH. Supracostal PCNL-Standard Nephrostomy with Day Long Pain Versus

Painless Tubeless. J Urol Surg 2018;5(2):73-77

๑Copyright 2018 by the Association of Urological Surgery / Journal of Urological Surgery published by Galenos Publishing House. 


\section{Öz}

hastanın 1'inde (\%4) plevral efüzyon gelişti. Grup A'da $2(\% 8)$ hasta ve grup B'de $1(\% 4)$ hasta torakostomi yerleştirilmesini gerektirdi ( $p=0,56)$. Her bir grupta 1 hastada (\%2) elektif entübasyon ve ventilasyona ihtiyaç duyan respiratuvar distres gelişti $(p=1,00)$. B grubu $(4,12 \pm 0,52$ gün) için

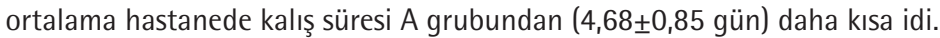

Sonuç: Tüpsüz suprakostal PNL, komplikasyon oranlarında fark olmaksızın tüplü suprakostal PNL'den daha az ağrılıdır. Tüpsüz suprakostal PNL daha az hastanede kalış süresine sahiptir.

Anahtar Kelimeler: Perkütan nefrolitotomi, Suprakostal, Plevral efüzyon, Torakostomi

\section{Introduction}

Percutaneous nephrolithotomy (PCNL) is known to provide best stone-free rate among all available treatments for renal stones $(1,2)$ and it has been recommended as "standard" for stones larger than $20 \mathrm{~mm}$. Safety of PCNL has been established on the basis of various studies and resources (3).

On most of the occasions, access into the kidney is acquired subcostally. However, in case of bulk stone or multiplicity, for better clearance of stones, pelvicalyceal system is accessed through upper calyceal system supracostally because of large stone size and anatomical alignment with other calyces and pelvis $(4,5)$. Since the tube in supracostal PCNL is likely to move with every breath, more pain is expected leading to higher and frequent doses of analgesia. In the literature, there are several studies supporting the safety and efficacy of tubeless (TL) and totally TL PCNL with shorter hospital stay compared to standard PCNL with nephrostomy $(6,7)$.

Literature regarding TL supracostal PCNL is not only sparse but also the recent guidelines have not established practices of such an entity. The major concern in TL supracostal PCNL is increased thoracic complications, such as pleural effusion, need for thoracostomy and endotracheal intubation with mechanical ventilation, but the limitedly literature available has not shown any major difference between two approaches in terms of pulmonary complications (TL $9.3 \%$ vs. standard $9.6 \%)(8,9)$.

Though the superior calyx is one of the preferred puncture sites for PCNL for its shortest course from the skin to the system and maximal maneuverability $(10,11,12)$, increased risk of pulmonary complications has been concerning for many. Historically, the safety against pulmonary complications in supracostal PCNL has been improved with the use of nephrostomy tube but that notion is still debatable and there exists a strong need for prospective trials to evaluate the safety of this procedure without leaving a nephrostomy tube in situ. Such future studies will not only improve our knowledge of supracostal PCNL, but will also shape and strengthen the current urological guidelines.

\section{Materials and Methods}

This randomized controlled trial took place at the Kidney Centre Postgraduate Training Institute, Karachi, Pakistan from September 2013 to February 2015. Native ethical review board approval was taken prior to the study (Kidney Centre Ethical Review Committee reference \# 01-URO-032013).

Sample size calculation was based on historical cohort of one of the previously performed and published similar trials (9) due to the sparse data. This yielded a sample size of 50 patients ( 25 patients in each arm). All adult patients ( $>14$ years), who were electively admitted for PCNL, were informed about the trial in detail and, after obtaining informed consent, were proviionally enrolled in the study. Final decision for enrollment in the study was performed on the operating table once retrograde urography was performed and decision for supracostal access was established. Patients who did not require supracostal access were excluded from the study. After enrollment, the patients were randomized into two groups ( 25 patients each) by stratifying odd number for supracostal PCNL with tube (WT) as group A and for supracostal TL PCNL as group B.

Access was acquired in the prone position and puncture was performed with a spinal needle using the Bull's eye or triangulation technique under fluoroscopic guidance. Urologists of at least 10 years' experience performed the procedures with grossly similar operative technique. Patients, who underwent more than one puncture or severe bleeding, were excluded from the study (only one patient in group A underwent double puncture and was excluded with random replacement by another patient to maintain equal number arms). Age, gender, punctured calyx, visual analogue scale (VAS) score and hospital stay were recorded in all patients.

Both groups received post-operative injectable analgesia on operative day and oral analgesia from first post-operative day. Pain severity objectively assessed by a VAS. Chest X-ray and ultrasonography of the kidney were done to detect any pleural effusion and perinephric collection. Patients, who demonstrated respiratory distress clinically and with radiological evidence of fluid, underwent thoracostomy. Few patients, who did not resolve after thoracostomy, needed endotracheal intubation and mechanical ventilation. These complications along with 
thoracostomy and endotracheal intubation were compared between the groups.

This study required two additional investigations consisting of postoperative day chest X-ray and ultrasonography of the kidney for perinephric collection other than the routine ones. Furthermore, the cost of thoracostomy and ventilatory support was also to be reimbursed through institutional grant. Therefore, this grant was also approved along with the ethical review board approval for the additional investigations and thoracostomy with or without ventilation, if needed.

\section{Statistical Analysis}

The results were described in terms of mean and standard deviation for continuous variables (age, punctured calyx, VAS score and duration of the procedure). Categorical variables, such as gender and punctured calyx, were described in terms of percentage and were compared between the 2 groups using a chi-square test. Data was analyzed using SPSS (Statistical Packages of Social Sciences) version 20. effect modifiers/ confounders (size of stone and duration of procedure) were analyzed through stratification and a chi-square test was applied. A p value of less than 0.05 was considered statistically significant.

\section{Results}

The mean (VAS) score in groups $A$ and $B$ was $7.88 \pm 0.83$ and $4.12 \pm 0.83$, respectively $(p=0.01)$, as shown in Table 1 .

Four (16\%) patients in group A and 1 (4\%) patient in group B developed pleural effusion, as shown in Table 1.

Two patients (8\%) in group A and 1 patient (4\%) in group B required thoracostomy $(p=0.56)$, as shown in Table 1 .

One patient (4\%) in group $A$ and 2 patients $(8 \%)$ in group $B$, developed perinephric collection $(p=0.56)$, as shown in Table 1.

A single patient in each group (2\%) developed respiratory distress needing elective intubation and ventilation $(p=1.00)$, as shown in Table 1.

The mean hospital stay in group B $(4.12 \pm 0.52$ days $)$ was shorter than in group $A(4.68 \pm 0.85$ days $)(p=0.01)$, as shown in Table 1.

\section{Discussion}

Supracostal PCNL is considered to be the easiest and most maneuverable puncture because of the distinct anatomy of the superior calyx and the alignment with other calyces and the pelvis. Nearly every part of the calyceal system is accessible through this route. However, the close proximity with pleural reflection makes urologists cautious against pulmonary complications. The present study was conducted to prove the widely unaccepted notion that supracostal PCNL is a very useful, yet quite safe procedure, such that it becomes part of future guidelines. Weighing the risks and benefits surely gives

Table 1. Baseline demographics and clinical characteristics

\begin{tabular}{ll}
\hline Group-A & $\begin{array}{l}\text { Group-B } \\
\text { (Supracostal PCNL WT) } \\
\text { (Supracostal } \\
\text { PCNL TL) }\end{array}$ \\
\hline
\end{tabular}

\begin{tabular}{|c|c|c|c|}
\hline Number of patients (n) & $\begin{array}{l}\text { Number of } \\
\text { patients (n) }\end{array}$ & $\begin{array}{l}p \text { value } \\
\text { (p) }\end{array}$ & \\
\hline \multicolumn{4}{|l|}{ Gender } \\
\hline Male & 18 & 17 & $p=1.000$ \\
\hline Female & 07 & 08 & \\
\hline \multicolumn{4}{|l|}{ Age groups } \\
\hline $15-29$ & 09 & 05 & $p=0.310$ \\
\hline $30-39$ & 06 & 06 & \\
\hline $40-49$ & 05 & 03 & \\
\hline $50-59$ & 05 & 09 & \\
\hline $60-75$ & 0 & 02 & \\
\hline \multicolumn{4}{|l|}{ Stone clearance } \\
\hline Complete & 19 & 23 & $p=0.382$ \\
\hline Residual <1cm & 05 & 02 & \\
\hline Residual >1cm & 01 & 0 & \\
\hline \multicolumn{4}{|l|}{ VAS scoring for pain } \\
\hline $\begin{array}{l}\text { Mild pain } \\
\text { (Score: } 1-4)\end{array}$ & 0 & 18 & $p=0.000$ \\
\hline $\begin{array}{l}\text { Moderate pain } \\
\text { (Score: } 5-7 \text { ) }\end{array}$ & 07 & 07 & \\
\hline $\begin{array}{l}\text { Severe pain } \\
\text { (Score: 8-10) }\end{array}$ & 18 & 0 & \\
\hline \multicolumn{4}{|l|}{ Hospital stay } \\
\hline 3 days & 0 & 01 & $p=0.013$ \\
\hline 4 days & 12 & 21 & \\
\hline 5 days & 11 & 02 & \\
\hline 6 days & 0 & 01 & \\
\hline 7 days & 02 & 0 & \\
\hline
\end{tabular}

Perinephric collection

$01 \quad 02 \quad p=0.500$

Pleural effusion

Mild effusion

02

0

$p=0.282$

(Conservatively treated)

Significant effusion

02

01

Endotracheal intubation \& mechanical ventilation

$0101 \quad p=1.000$

PCNL: Percutaneous nephrolithotomy, WT: With tube, TL: Tubeless, VAS: Visual analogue scale 
us a winner. However, as every guideline needs more evidence, this study is aimed to strengthen that evidence.

In their study including 840 patients who underwent PCNL between 2004 and 2007, Shah et al. (7) compared demographic and perioperative data of 454 patients who underwent TL PCNL with 386 patients who underwent PCNL. They found out that decrease in hemoglobin, transfusion rate, complications and stone-free rate were comparable between the groups. They reported that analgesia requirement was less $(p=0.000)$ and hospitalization duration was shorter $(p=0.000)$ in the TL PNCL group.

Efficacy of supracostal PCNL is also supported by Sekar et al. (12) In their study including 376 patients who underwent PCNL from July 2012 to Dec 2015, 92 needed supracostal puncture. Complete stone-free status was achieved in $83 \%$ of patients after initial PCNL. They concluded that supracostal PCNL was a safe and effective option in selected patients.

Between March 2005 and February 2012, 243 patients had a supracostal access in a study performed by Kara et al. (13) in which PCNL was performed by making the puncture through either $11^{\text {th }}$ or $10^{\text {th }}$ intercostal space. The stone-free rate was $86.8 \%$ in $11^{\text {th }}$ intercostal group and $84.6 \%$ in $10^{\text {th }}$ intercostal group. Twenty patients $(8.2 \%)$ encountered grade- 1 complications, 38 patients (15.6\%) showed grade-2 complications, 13 patients (5.3\%) faced grade-3a complications, only 2 patients $(0.8 \%)$ had grade- $3 \mathrm{~b}$ complications, while grade-4a was recorded in only $1(0.4 \%)$ patient. No grade- $4 b$ or grade- 5 complications were recorded. Overall complication rate was recorded to be $30.9 \%$ in $11^{\text {th }}$ intercostal and $28.2 \%$ in $10^{\text {th }}$ intercostal group.

Gonen et al. (14) performed a similar study including 10 patients as study group who underwent supracostal PCNL without nephrostomy tube between March 2005 and June 2007. These 10 patients were compared with 10 patients of control group who underwent supracostal PCNL with nephrostomy tube. The patients undergoing TL and stentless PCNL required less analgesia $(p=0.001)$ and were discharged earlier $(p=0.000)$ than those in the control group. Mean fall in hemoglobin and thoracic complications were insignificant and comparable between the 2 groups in this study.

\section{Study Limitations}

The present study supports the hypothesis of few of the internationally published articles with inference that nephrostomy tube is not needed to prevent the pulmonary complications in supracostal PCNL. The level of puncture (supra $11^{\text {th }}$ or supra $12^{\text {th }}$ rib) (15) also has a great impact on the outcome of safety, but due to limited scope of patients requiring supracostal access, this confounder was not assessed in the current study and turns out to be a single limitation of this study. Perinephric collection seemed to be the only preventable complication in the supracostal PCNL (WT) group, but the number of such patients was insignificant. Furthermore, this complication is self-limiting and trivial, seldom causing progression. Pulmonary complications hold the major attention in urology fraternity, and the fear is so substantial that supracostal access is reserved as a last resort by some urologists.

Another possible limitation of the study could be the use of $30 \mathrm{Fr}$ Amplatz sheath in all patients, which could have given different outcomes if a smaller sized access sheath was used, however, published literature also has limited data about this fact.

\section{Conclusion}

Supracostal TL PCNL is less painful than supracostal PCNL WT, without difference in complication rates in terms of pleural effusion, perinephric collection, thoracostomy and endotracheal intubation. Furthermore, the TL group had a shorter hospital stay than the PCNL WT group. This study is likely to add to strength of evidence on the subject and will highlight the issue to be incorporated into guidelines for standardization in stone treatment.

\section{Ethics}

Ethics Committee Approval: This study was approved by the Kidney Centre Ethical Review Committee (approval number: 01URO-032013, date: March 2013).

Informed Consent: Contained brief description about the study and disclosure about possible long term benefits of study, along with patient confidentiality policy. It was present in English and Urdu languages.

Peer-review: Externally peer-reviewed.

\section{Authorship Contributions}

Surgical and Medical Practices: A.S., S.E.K., S.S., Concept: A.S., S.M.M., Design: A.S., S.M.M., Data Collection or Processing: A.S., S.A.K., M.H.M., Analysis or Interpretation: A.S., Literature Search: A.S., S.M.M., Writing: A.S.

Conflict of Interest: No conflict of interest was declared by the authors.

Financial Disclosure: No funding or benefit of any kind was received other than the institutional grant which was approved prior to the study. Patient did not bear any additional investigation other than the routine. 


\section{References}

1. Preminger GM, Assimos DG, Lingeman JE, Nakada SY, Pearle MS, Wolf JS Jr; AUA Nephrolithiasis Guideline Panel). Chapter 1: AUA guideline on management of staghorn calculi: diagnosis and treatment recommendations. J Urol 2005;173:1991-2000.

2. Shahrour K, Tomaszewski J, Ortiz T, Scott E, Sternberg KM, Jackman SV, Averch TD. Predictors of Immediate Postoperative Outcome of Single-tract Percutaneous Nephrolithotomy. Urology 2012;80:19-26.

3. Ritter $M$, Krombach $P$, Michel MS. Percutaneous stone removal. European Urology Supplements 2011;10:433-439.

4. Shah HN, Hegde SS, Shah JN, Bansal MB. Safety and efficacy of supracostal access in tubeless percutaneous nephrolithotomy. J Endourol 2006;20:1016-1021.

5. Maheshwari PN, Andankar M, Hedge S, Bansal M. Supra-costal approach for PCNL. BJU Int 2000;85:557.

6. Al-Ba'adani TH, Al-Kohlany KM, Al-Adimi A, Al-Towaity M, Al-Baadani T, Alwan M, Al-Hussieni M, Al-Germozi S, Al-Masani M, Al-Badwy K, El-Nono IH. Tubeless percutaneous neprolithotomy: the new gold standard. Int Urol Nephrol 2008;40:603-608.

7. Shah H, Khandkar A, Sodha H, Kharodawala S, Hegde S, Bansal M. Tubeless percutaneous nephrolithotomy: 3 years of experience with 454 patients. BJU Int 2009;104:840-846.

8. Jun-Ou J, Lojanapiwat B. Supracostal access: does it affect tubeless percutaneous nephrolithotomy efficacy and safety? Int Braz J Urol 2010;36:171-176.
9. Sofikerim $M$, Demirci $D$, Huri $E$, Erşekerci $E$, Karacagil $M$. Tubeless percutaneous nephrolithotomy: safe even in supracostal access. J Endourol 2007;21:967-972.

10. Gupta R, Kumar A, Kapoor R, Srivastava A, Mandhani A. Prospective evaluation of safety and efficacy of the supracostal approach for percutaneous nephrolithotomy. BJU Int 2002;90:809-813.

11. Lojanapiwat B, Prasopsuk S. Upper-pole access for percutaneous nephrolithotomy: comparison of supracostal and infracostal approaches. J Endourol 2006;20:491-494.

12. Sekar H, Krishnamoorthy $S$, Kumaresan $N$, Ramanan V. Supracostal Punctures for PCNL: Factors that Predict Safety, Success and Stone Free Rate in Stag Horn and Non-Stag Horn Stones: A Single Centre Experience and Review of Literature. J Clin Diagn Res 2016;10:PC17-PC21.

13. Kara C, Değirmenci T, Kozacioglu Z, Gunlusoy B, Koras O, Minareci S. Supracostal Approach for PCNL: Is 10th and 11th Intercostal Space Safe According to Clavien Classification System? Int Surg 2014;99:857-862.

14. Gonen M, Cicek T, Ozkardes H. Tubeless and stentless percutaneous nephrolithotomy in patients requiring supracostal access. Urol Int 2009;82:440-443.

15. Kara C, Değirmenci T, Kozacioglu Z, Gunlusoy B, Koras O, Minareci S. Supracostal Approach for PCNL: Is 10th and 11th Intercostal Space Safe According to Clavien Classification System? Int Surg 2014;99:857-862. 